\title{
Gold Mining and Mercury Bioaccumulation in a Floodplain Lake and Main Channel of the Tambopata River, Perú
}

\author{
Katherine A. Roach ${ }^{1}$, Nicolas F. Jacobsen², Christine V. Fiorello ${ }^{3}$, Amanda Stronza ${ }^{2}$, \\ Kirk O. Winemiller ${ }^{1}$ \\ ${ }^{1}$ Department of Wildlife and Fisheries Sciences, Texas A\&M University, College Station, USA; ${ }^{2}$ Department of Recreation, Park and \\ Tourism Sciences, Texas A\&M University, College Station, USA; ${ }^{3}$ Wildlife Health Center, School of Veterinary Medicine, Univer- \\ sity of California, Davis, USA. \\ Email: roackat@gmail.com
}

Received November $2^{\text {nd }}, 2012$; revised November $30^{\text {th }}, 2012$; accepted December $29^{\text {th }}, 2012$

\begin{abstract}
Contamination of water bodies by inorganic mercury $(\mathrm{Hg}[\mathrm{II}])$ used in placer mining of gold deposits in the Madre de Dios Department, Perú, contributes to the bioaccumulation of methylmercury $(\mathrm{MeHg})$ in fish tissue. We measured $\mathrm{MeHg}$ and total $\mathrm{Hg}$ (THg) concentrations ( $\mathrm{mg} / \mathrm{kg}$ wet weight $[\mathrm{ww}]$ tissue) of thirteen fish species from the Tambopata River, Perú, and the connected oxbow lake Tres Chimbadas. We also used stable isotope analysis $\left(\delta^{15} \mathrm{~N}\right.$ and $\left.\delta^{13} \mathrm{C}\right)$ to estimate trophic positions of fishes. Average MeHg concentrations of fish species ranged from $0.042 \mathrm{mg} / \mathrm{kg}$ ww ( $\mathrm{Sa}$ tanoperca jurupari) to $0.463 \mathrm{mg} / \mathrm{kg}$ ww (Hoplias malabaricus) in the main channel and from $0.090 \mathrm{mg} / \mathrm{kg} \mathrm{ww}$ (Parauchenipterus sp.) to $1.282 \mathrm{mg} / \mathrm{kg}$ ww (Pimelodina flavipinnis) in the lake. Spearman rank correlation indicated that trophic position had no influence on $\mathrm{MeHg}$ concentrations of species in the main channel, but in the lake, trophic positions of species were positively associated with $\mathrm{MeHg}$. Migrations of the pimelodid catfish surveyed from the main channel are well documented. Because little gold mining occurs at our study site, fishes from the main channel may be bioaccumulating $\mathrm{MeHg}$ from areas where mining is widespread. Fish species that reside in the lake are relatively sedentary and migration is limited by the brief period of floodplain inundation and the long, narrow corridor that connects the lake to the main channel; lake sediments are therefore the likely source for MeHg bioaccumulation. Five out of the eight fish species surveyed from the main channel and two out of the five species from the lake had MeHg levels higher than United States Environmental Protection Agency fish tissue criterion for human consumption.
\end{abstract}

Keywords: Fishes; Giant Otter; Gold Mining; Mercury; Methylmercury; Perú

\section{Introduction}

Mercury $(\mathrm{Hg})$ is a pollutant that can cause developmental and behavioral abnormalities including impaired reproduction and decreased survival in vertebrates [1]. Methylmercury (MeHg) is the form of most concern because, unlike inorganic $\mathrm{Hg}(\mathrm{Hg}[\mathrm{II}])$ which is readily excreted from the body, $\mathrm{MeHg}$ bioaccumulates and can reach harmful levels in fish tissues [2]. The US Environmental Protection Agency estimates (with uncertainty spanning an order of magnitude) that $\mathrm{Hg}$ exposure of the human population, including sensitive subgroups, of 0.0001 $\mathrm{mg} / \mathrm{kg} /$ day is likely to be without appreciable risk of deleterious effects during a lifetime [3]. Based on this estimate, the USEPA recommends that $0.3 \mathrm{mg} \mathrm{MeHg} / \mathrm{kg}$ wet weight (ww) tissue should not be exceeded to protect the health of consumers of noncommercial freshwater and estuarine fish [3].

In the Madre de Dios department, Perú, placer mining of gold deposits is believed to have contributed to increased $\mathrm{Hg}(\mathrm{II})$ concentrations in the water and sediments of some rivers. This is of concern for local people because they consume large amounts of fish from local rivers. Traditionally, fish were the most significant source of animal protein for local people, and while diets have diversified due to an increase in ranching as well as connection to national and global markets, locally caught fish remain an important part of the diet. The majority of gold mining operations in Madre de Dios are relatively small scale (e.g., family-operated placer mines), but in recent years both the number and scale of these operations have increased [4]. With the recent rise in worldwide gold prices (currently $>\$ 1500$ /ounce), there is economic pressure to expand this industry $[5,6] . \mathrm{Hg}(\mathrm{II})$ is 
used to amalgamate gold from river sediment, and during this process up to $20 \%$ of the $\mathrm{Hg}$ used is lost into the river. Another $20 \%$ can then be lost to the atmosphere in the subsequent process of heating the metal to separate the Hg from the gold [7]. Because estimates of Hg pollution from gold mining are imprecise, little is known about sources and sinks for $\mathrm{Hg}$ in Madre de Dios watersheds. Oxbow lakes in this region have been hypothesized to retain $\mathrm{Hg}$ because they have high sediment organic matter content [8]. Impacts from placer gold mining operations in this region also have been suggested to be limited to river reaches immediately downstream of mining sites [9], which implies that fish with high concentrations of $\mathrm{MeHg}$ do not move very far from the source of contamination. Given the great extent of mining activity and the long-distance movements of many of the fish species consumed by humans in this region [10], $\mathrm{Hg}$ pollution from gold mining poses a potentially serious risk to human health.

Humans are not the only species affected by Hg pollution and bioaccumulation; the entire aquatic ecosystem can be negatively impacted. At MeHg dietary concentrations of $0.5 \mathrm{mg} / \mathrm{kg}$ ww, many fish species experience impaired reproduction, and significant mortality occurs at concentrations $>1.9 \mathrm{mg} / \mathrm{kg} \mathrm{ww}$ [11]. A species of particular concern is the giant otter, Pteronura brasiliensis, listed as endangered by the International Union for Conservation of Nature [12]. A flagship species for both conservation and ecotourism in the Madre de Dios region, giant otters are an apex predator in the aquatic food web residing in rivers and, more frequently, lakes. Their diet consists almost exclusively of fish, and many of their preferred prey species occupy relatively high trophic positions $[4,13]$. In addition, giant otters have high metabolic rates; to support this energy consumption, they consume up to $4 \mathrm{~kg}$ of fish per day [4]. While very little is known about the impacts of $\mathrm{MeHg}$ accumulation on giant otters of South America, studies indicate that mammalian wildlife and humans respond to $\mathrm{MeHg}$ in a comparable manner [14]. Furthermore, other members of the family Mustelidae including otter species in North America and Europe (Lutra canadensis, Lutra lutra) and American mink (Mustela vison) are highly sensitive to $\mathrm{Hg}$, with neurochemical changes in the brain occurring at $\mathrm{MeHg}$ dietary concentrations of $0.5 \mathrm{mg} / \mathrm{kg}$ [15-17].

The aquatic $\mathrm{Hg}$ cycle is complex, with many interrelated factors determining fish $\mathrm{MeHg}$ concentrations. The fundamental drivers of this process include $\mathrm{Hg}$ deposition, the transformation of inorganic $\mathrm{Hg}$ (II) to $\mathrm{MeHg}$ by sulfate-reducing bacteria under anoxic environmental conditions [18], and rates of $\mathrm{MeHg}$ uptake and trophic transfer [19,20]. Comparisons of species' trophic positions and $\mathrm{MeHg}$ concentrations can allow for inferences to be made about the factors that influence MeHg bioac- cumulation. Nitrogen stable isotope ratios $\left(\delta^{15} \mathrm{~N}\right)$ can be used to estimate consumer trophic positions because tissue becomes more enriched in ${ }^{15} \mathrm{~N}$ with each subsequent trophic transfer ["fractionation", 21,22]. However, the $\delta^{15} \mathrm{~N}$ signature of primary producers can vary among habitats, thus a baseline $\delta^{15} \mathrm{~N}$ must first be taken into account. Because $\delta^{13} \mathrm{C}$ does not fractionate up the food chain, it is useful for estimating the basal production sources (i.e., algae, terrestrial plants) from which a consumer derives its baseline $\delta^{15} \mathrm{~N}$.

Our major objectives of the present study were to measure total $\mathrm{Hg}(\mathrm{THg})$ and $\mathrm{MeHg}$ concentrations and trophic positions of thirteen fish species, including six species that are important food resources for humans and giant otters, in the Tambopata River and the oxbow lake Tres Chimbadas, Perú to determine if $\mathrm{Hg}$ levels were above USEPA fish tissue criterion. We then examined how the relationship between trophic position and $\mathrm{MeHg}$ of fish species varied between the main channel and oxbow lake. We also measured $\mathrm{Hg}$ (II) concentrations and organic matter content of sediment in both habitats. Finally, we compared our results with those of other studies of $\mathrm{Hg}$ concentrations in fish from aquatic ecosystems in the Madre de Dios Department, Perú.

\section{Study Area}

The Tambopata River (Figure 1) is a meandering, socalled whitewater river (i.e., carries high suspended sediment loads) that originates in the Andean piedmont of Perú, meets the Madre de Dios River in Perú, and meets the Amazon River in Brazil. The hydrologic regime shows a distinct seasonal flow pattern; stage height is generally highest from February to March and lowest from August to September, however rapid fluctuations in stage height of $2-3 \mathrm{~m}$ per day can occur at any time of the year [23]. Suspended sediment load is high due to erosion of the Andes, and the low-gradient, deep alluvial sediments, and variable discharge produce lateral channel migrations [24]. A small stream flows from the oxbow lake Tres Chimbadas to the main channel. In our study region, the floodplain mostly consists of intact moist tropical forest, but smallscale farming and cattle ranching also occur. Tres Chimbadas supports giant otters and was designated a conservation reservation by the local Ese'eja native community of Infierno, thus neither mining nor fishing for consumptive purposes are permitted [25].

\section{Materials and Methods}

\subsection{Sample Collections}

From May to August 2009, fishes were collected from the main channel and lake with seines, cast nets, and hook and line. Following euthanasia, an approximately $5-10 \mathrm{~g}$ 


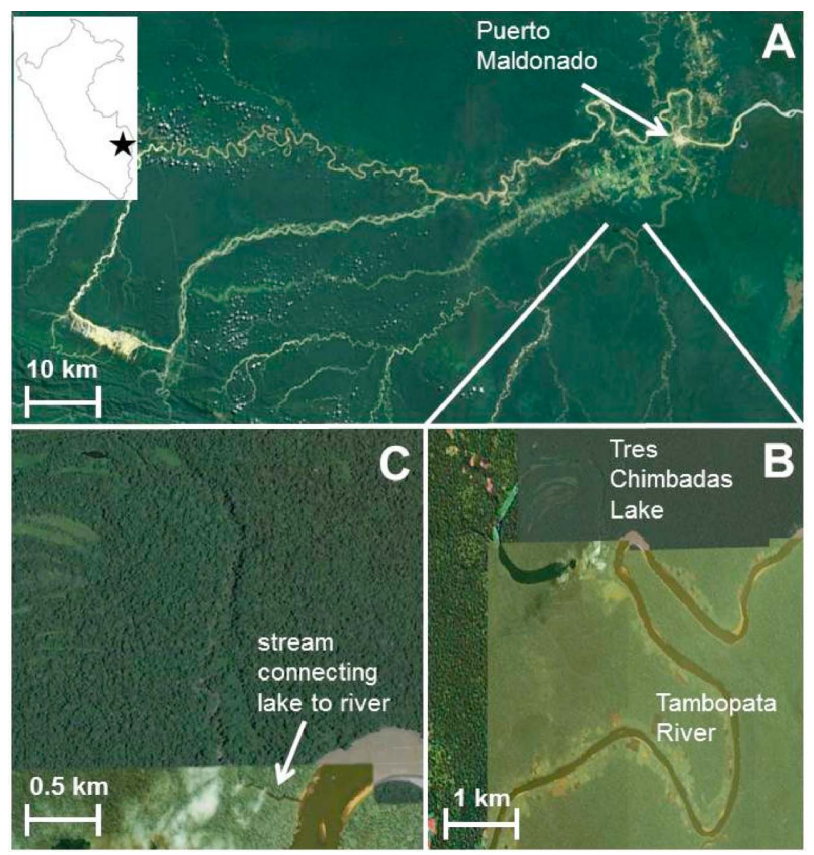

Figure 1. (A) Map of the study site ca. $25 \mathrm{~km}$ southwest of Puerto Maldonado, Perú. Changes in geomorphology of the Inambari River as a result of placer mining can be observed on the bottom left of the photograph; (B) Tres Chimbadas Lake and the Tambopata River main channel where samples were collected for mercury and stable isotope analysis. Latitude ( $\left.{ }^{\circ} \mathrm{S}\right) /$ longitude $\left({ }^{\circ} \mathrm{W}\right)$ of habitats: Tres Chimbadas Lake, 12.47.2246/69.20.4462; Tambopata River main channel, 12.48.0406/69.17.3063; (C) The small stream that permanently connects Tres Chimbadas to the main channel.

sample of muscle tissue from each individual was removed from the dorso-lateral region using a scalpel. Subsamples of tissue for analysis of $\mathrm{Hg}$ were placed in acidwashed bottles filled with ethanol, and sub-samples for stable isotope analysis were placed in a plastic bag with salt, a preservation method that has minimal influence on stable isotope signatures [26]. A minimum of $100 \mathrm{~g}$ of bed sediment was collected using a shovel and hand trough. A surficial sample was taken first, sealed in a plastic bag, and labeled. A shovel was then used to dig at least $30 \mathrm{~cm}$ deep or until the color and texture of the sediment changed. At this point, a deep sediment sample was collected in the same manner. For each location, this process was repeated at two additional sites, each separated by at least $20 \mathrm{~m}$. Samples for $\mathrm{Hg}$ analysis were preserved by freezing. Sediment surface samples for analysis of organic content were collected by inverting a Petri dish $(5-\mathrm{cm}$ diameter and $1.3-\mathrm{cm}$ height), pressing the edge into the sediment, and capping it with a spatula. These samples were preserved in 10\% formalin. Samples for $\mathrm{Hg}$ analysis were transported to the University of Georgia, and samples for stable isotope analysis and sediment organic matter content were transported to Texas

\section{A\&M University for processing.}

\subsection{Analytical Methods}

Each set of triplicate sediment samples was pooled prior to $\mathrm{Hg}$ analysis. Samples of fish muscle and sediment for $\mathrm{Hg}$ analysis were sent to a commercial analytical laboratory (Quicksilver Scientific, Lafayette, CO, USA) for analysis using high pressure liquid chromatography speciation analysis (QS-LC/CVAF-001) to determine $\mathrm{Hg}(\mathrm{II})$ and $\mathrm{MeHg}$ [27]. Several quality control measures were taken during the analysis, including 2 blanks, 2 reference materials, 2 matrix spike duplicates, 2 laboratory control samples, and 2 sample duplicates. Method detection limits for fish tissue were $175.5 \mathrm{pg} / \mathrm{g} \mathrm{MeHg}$ and $445.0 \mathrm{pg} / \mathrm{g}$ $\mathrm{Hg}$ (II). Recovery of control samples was $102.0 \%$ for $\mathrm{MeHg}$ and $100.3 \%$ for THg. The average relative percent difference in THg of duplicate samples was $5.55 \%$. We assumed $80 \%$ moisture in fish tissue samples [28] and thus a conversion factor of 5 was used to convert dry to wet weight in order to compare samples with USEPA guidelines.

At the laboratory at Texas A\&M University, samples for stable isotope analysis were rinsed and soaked for $4 \mathrm{~h}$ in deionized water to remove salt. Samples were dried at $65^{\circ} \mathrm{C}$ for $48 \mathrm{~h}$, ground to a fine powder using a mortar and pestle, and weighed into Ultra-Pure tin capsules (Costech Analytical, Valencia, CA, USA). Samples were subsequently sent to the W.M. Keck Paleoenvironmental and Environmental Stable Isotope Laboratory, University of Kansas, Lawrence, KS, USA, for analysis of carbon and nitrogen isotope ratios on a ThermoFinnigan MAT 253 continuous-flow mass spectrometer using standards of Pee Dee Belemnite limestone for carbon isotopes and atomspheric nitrogen for nitrogen isotopes. We measured sediment organic matter content using the $\%$ ash-free dry mass method [29].

\subsection{Data Analysis}

Trophic position estimates were calculated based on a standard two-source mixing model using the equation $T P=\lambda+$

$$
\left(\delta^{15} N_{\text {sc }}-\left[\left(\delta^{15} N_{\text {base } 1} \times \alpha+\delta^{15} N_{\text {base } 2} \times(1-\alpha)\right]\right) / 2.54\right.
$$

where $\lambda$ was the trophic level of the food base (2 for primary consumers), $\alpha$ was the proportion of ${ }^{15} \mathrm{~N}$ in the consumer derived from base 1 , and $2.54 \%$ was the average trophic fractionation value $[21,22]$. We estimated $\alpha$ using the equation $\left(\delta^{13} \mathrm{C}_{\mathrm{sc}}-\delta^{13} \mathrm{C}_{\text {base } 2}\right) /\left(\delta^{13} \mathrm{C}_{\text {base } 1}-\delta^{13} \mathrm{C}_{\text {base } 2}\right)$. Because primary consumers integrate the temporal and spatial variability in stable isotope signatures of primary producers [21], we selected two common primary consumers to estimate the baseline. The fish species Prochilodus nigricans (Characiformes: Prochilodontidae) assimilates autochthonous algae and detritus, and was 
present in both the lake and main channel. We selected two fish species that assimilate terrestrial plants: Astyanax abramoides (Characiformes: Characidae) from the lake and Brycon amazonicus (Characiformes: Characidae) from the main channel.

Spearman rank correlation was used to examine the relationship between average trophic positions and average $\mathrm{MeHg}$ concentrations of fish species in each habitat. Student's t-tests were used to examine between-habitat differences in sediment organic matter content. Statistical analyses were performed in SPSS, and results were considered statistically significant at $\alpha=0.05$.

\section{Results}

\subsection{Hg Concentrations}

$\mathrm{THg}$ in individual fishes ranged from 0.035 to 1.351 $\mathrm{mg} / \mathrm{kg}$ ww tissue, and $\mathrm{MeHg}$ ranged from 0.035 to 1.282 $\mathrm{mg} / \mathrm{kg}$ ww tissue. Fishes from the main channel generally had higher THg (range 0.095 to $1.351 \mathrm{mg} / \mathrm{kg}$ ww tissue, average of all species surveyed $=0.586 \mathrm{mg} / \mathrm{kg}$ ww tissue) and $\mathrm{MeHg}$ (range 0.090 to $1.282 \mathrm{mg} / \mathrm{kg}$ ww tissue, average for all species surveyed $=0.562 \mathrm{mg} / \mathrm{kg}$ ww tissue) concentrations than fishes from the lake $\mathrm{THg}$ range 0.043 to $0.466 \mathrm{mg} / \mathrm{kg}$ ww tissue and average for all species surveyed $=0.219 \mathrm{mg} / \mathrm{kg}$ ww tissue; $\mathrm{MeHg}$ range 0.042 to $0.463 \mathrm{mg} / \mathrm{kg} \mathrm{ww}$ tissue and average for all species surveyed $=0.217 \mathrm{mg} / \mathrm{kg}$ ww tissue; Table $\mathbf{1}$ ).

$\mathrm{MeHg}$ concentrations in some fishes from both the lake and the main channel were above USEPA fish tissue criterion. In the lake, piraña (Serrasalmus sp., 0.304 $\mathrm{mg} / \mathrm{kg}$ ww tissue) and huasaco (Hoplias malabaricus, $0.463 \mathrm{mg} / \mathrm{kg}$ ww tissue) were above USEPA fish tissue criterion, and in the main channel, toa (Platystomatichthys sturio, $0.590 \mathrm{mg} / \mathrm{kg}$ ww tissue), zungaro (Zungaro zungaro, $0.642 \mathrm{mg} / \mathrm{kg}$ ww tissue), maparate gordo (Ageneiosus brevifilis, $0.733 \mathrm{mg} / \mathrm{kg}$ ww tissue), mota fina (Pinirampus pirinampu, $0.974 \mathrm{mg} / \mathrm{kg}$ ww tissue), and mota con puntos (Pimelodina flavipinnis, $1.282 \mathrm{mg} / \mathrm{kg}$ ww tissue) were above USEPA criterion.

Table 1. Average ( $\pm \mathrm{SD})$ total length $(\mathrm{cm})$, methylmercury $(\mathrm{MeHg}, \mathrm{mg} / \mathrm{kg}$ wet weight tissue), and total mercury (THg, mg/kg wet weight tissue) concentrations in muscle tissue of fishes from the Tambopata River main channel and Tres Chimbadas oxbow lake, Perú. Common names of fishes and sample sizes are in parentheses next to species taxonomic names.

\begin{tabular}{|c|c|c|c|c|}
\hline Taxa & Total length (cm) & Habitat & MeHg & THg \\
\hline \multicolumn{5}{|l|}{ Characiformes } \\
\hline \multicolumn{5}{|l|}{ Characidae } \\
\hline Brachychalcinus sp. (mojarita, 1) & 6.3 & Lake & 0.053 & 0.054 \\
\hline Serrasalmus sp. (piraña, 2) & $15.5(0.5)$ & Lake & $0.304(0.138)$ & $0.320(0.142)$ \\
\hline \multicolumn{5}{|l|}{ Erythrinidae } \\
\hline Hoplias malabaricus (huasaco, 2) & $22.4(5.9)$ & Lake & $0.463(0.381)$ & $0.466(0.383)$ \\
\hline \multicolumn{5}{|l|}{ Perciformes } \\
\hline \multicolumn{5}{|l|}{ Cichlidae } \\
\hline Satanoperca jurupari (bujurqui, 2) & $15.2(1.0)$ & Lake & $0.042(0.011)$ & $0.043(0.011)$ \\
\hline \multicolumn{5}{|l|}{ Gymnotiformes } \\
\hline \multicolumn{5}{|l|}{ Sternopygidae } \\
\hline Sternopygus macrurus (macana, 1) & 32.0 & Main channel & 0.124 & 0.126 \\
\hline \multicolumn{5}{|l|}{ Siluriformes } \\
\hline \multicolumn{5}{|l|}{ Auchenipteridae } \\
\hline Ageneiosus brevifilis (maparate gordo, 1) & 50.8 & Main channel & 0.733 & 0.713 \\
\hline Parauchenipterus sp. (1) & 19.0 & Main channel & 0.090 & 0.095 \\
\hline \multicolumn{5}{|l|}{ Pimelodidae } \\
\hline Pimelodina flavipinnis (mota con puntos, 1 ) & 64.8 & Main channel & 1.282 & 1.351 \\
\hline Pimelodus blochii (bagre, 1) & 20.2 & Main channel & 0.091 & 0.092 \\
\hline Zungaro zungaro (zungaro, 1) & 92.7 & Main channel & 0.642 & 0.682 \\
\hline
\end{tabular}




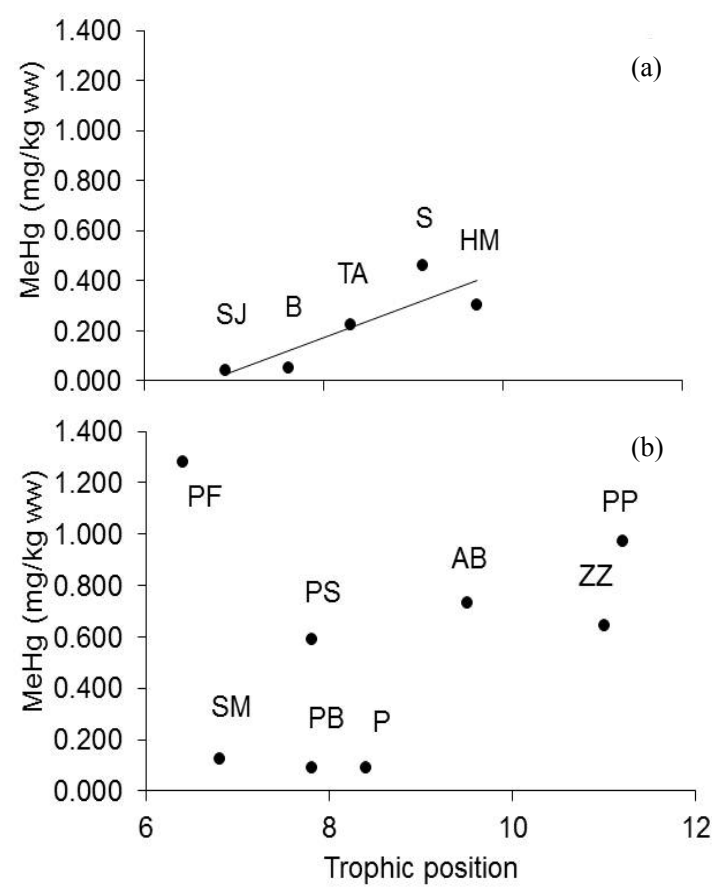

Figure 2. Relationship between average methylmercury (MeHg) muscle tissue concentrations ( $\mathrm{mg} / \mathrm{kg}$ wet weight) and trophic positions of fishes from (a) Tres Chimbadas Lake (SJ = Satanoperca jurupari, B = Brachychalcinus sp., $\mathrm{TA}=$ Triportheus angulatus, $\mathrm{S}=$ Serrasalmus sp., $\mathrm{HM}=$ Hoplias malabaricus) and (b) the Tambopata River main channel ( $\mathbf{P}=$ Parauchenipterus sp., $\mathbf{P B}=$ Pimelodus blochii, SM = Sternopygus macrurus, $\mathbf{P S}=$ Platystomatichthys sturio, $\mathrm{ZZ}=$ Zungaro zungaro, $\mathbf{A B}=$ Ageneiosus brevifilis, $\mathbf{P P}=$ Pinirampus pirinampu, and $\mathrm{PF}=$ Pimelodina flavipinnis). The regression line $(y=a x+c)$ is shown only for the statistically significant correlation obtained for plot (A).

\subsection{Trophic Positions}

In both habitats, the fishes with the highest $\mathrm{MeHg}$ concentrations were not feeding at the highest trophic positions (Figure 2). For example, in the main channel mota con puntos had $\mathrm{MeHg}$ concentrations two-fold higher than zungaro, however zungaro fed at a higher trophic position. Spearman rank correlation indicated that trophic position had no influence on $\mathrm{MeHg}$ in the main channel ( $\mathrm{rs}=0.12, \mathrm{p}=0.78)$. In the lake, species trophic positions were positively associated with $\mathrm{MeHg}$ ( $\mathrm{rs}=0.90, \mathrm{p}<$ 0.05 ; Figure 2).

\subsection{Sediment $\mathrm{Hg}(\mathrm{II})$ and Organic Matter Content}

$\mathrm{Hg}$ (II) concentration of sediment from Tres Chimbadas lake was higher (22 $\mathrm{ng} / \mathrm{g} \mathrm{ww})$ compared to sediment from the Tambopata River main channel (13 ng/g ww).

The high organic matter content of the lake sediment (average $=10.83 \%)$ indicates that anoxia likely occurs. In contrast, average sediment organic content was only
$0.54 \%$ in the main channel, probably due to resuspension and downstream transport. Differences in organic matter content were significant between the main channel and the lake (Student's t-test, $\mathrm{t}=6.44, \mathrm{df}=25, \mathrm{p}<0.001$ ).

\section{Discussion}

Most of the fishes from our study site had Hg concentrations within the range of concentrations found in fishes sampled from the Madre de Dios River near Puerto Maldonado; Rio de la Torre, a tributary of the Tambopata River; and the Puerto Maldonado fish market from 19901993 [8], and from the Puerto Maldonado fish market in 2008 [30] (Table 2). One fish from our study site, the pimelodid catfish mota con puntos, had $\mathrm{Hg}$ concentrations higher than levels reported previously for fishes from the Madre de Dios department. Three of the five fish species sampled by [8] within $100 \mathrm{~km}$ of the city of Puerto Maldonado, where mining of gold deposits is fairly common, were above the USEPA fish tissue criterion. Assuming that $95 \%$ of the $\mathrm{THg}$ present is $\mathrm{MeHg}$ [31], MeHg concentrations documented by [30] ranged from below detection for the characid Piaractus brachypomus to $1.072 \mathrm{mg} / \mathrm{kg}$ ww tissue for the Pimelodid catfish Calophysis macropterus. In contrast, fishes sampled by [8] from aquatic habitats inside Manu National Park from 1990-1993 seemed to have slightly lower Hg concentrations; two of the seven fish species sampled had MeHg concentrations above USEPA fish tissue criterion. Again assuming that $95 \%$ of $\mathrm{THg}$ is $\mathrm{MeHg}$, fishes sampled in 1997 by [32] from an isolated site with no gold mining and very low human population density on the Candemo River, Bahuaja-Sonene National Park, had much lower MeHg concentrations ranging from 0.012 $\mathrm{mg} / \mathrm{kg}$ ww tissue for the detritivore Prochilodus nigricans to $0.086 \mathrm{mg} / \mathrm{kg}$ ww tissue for Pseudoplatystoma sp., a carnivorous pimelodid catfish.

Potential sources of $\mathrm{Hg}$ (II) contamination at our study site include naturally occurring $\mathrm{Hg}$ from erosion of the Andes Mountains and precipitated $\mathrm{Hg}$ particles formed by atmospheric fumes or tailings from gold mining [10]. For example, cinnabar, the most common $\mathrm{Hg}$ ore, has been mined in the town of Huancavelica located in the Peruvian Andes for over 3000 years [33]. However, an enormous amount of $\mathrm{Hg}(\mathrm{II})$ has been used for gold extraction in the Madre de Dios Department in recent years; Peruvian Hg imports in 2009 were estimated at 175 tons [5], and more than $95 \%$ of imports are used for artisanal mining [34]. Additionally, the Madre de Dios Department has the greatest number of unapproved mining permits in Peru (i.e., final approval of a mining permit requires an environmental impact report, [35]) and produces $70 \%$ of the country's gold [34]. The high levels of imported $\mathrm{Hg}$ combined with the higher $\mathrm{Hg}$ concentra 
Table 2. Average methylmercury (MeHg, mg/kg wet weight tissue) and total mercury (THg, mg/kg wet weight tissue) concentrations of fishes from the Madre de Dios Department, Perú.

\begin{tabular}{|c|c|c|c|c|c|c|}
\hline System & Year sampled & Family & Genus Species & MeHg & THg & Reference \\
\hline Fish market, Puerto Maldonado & 2008 & Characidae & Hydrolycus pectoralis & N/A & 0.585 & {$[30]$} \\
\hline Fish market, Puerto Maldonado & 2008 & Characidae & Piaractus brachypomus & N/A & bd & {$[30]$} \\
\hline Fish market, Puerto Maldonado & 2008 & Curimatidae & Potamorhina altamazonica & $\mathrm{N} / \mathrm{A}$ & 0.021 & {$[30]$} \\
\hline Fish market, Puerto Maldonado & 2008 & Loricariidae & Pterygoplichthys sp. & N/A & 0.321 & {$[30]$} \\
\hline Fish market, Puerto Maldonado & 2008 & Pimelodidae & Calophysus macropterus & $\mathrm{N} / \mathrm{A}$ & 1.128 & {$[30]$} \\
\hline Fish market, Puerto Maldonado & 2008 & Pimelodidae & Pimelodus sp. & $\mathrm{N} / \mathrm{A}$ & 0.120 & {$[30]$} \\
\hline Fish market, Puerto Maldonado & 2008 & Pimelodidae & Pseudoplatystoma fasciatum & N/A & 0.321 & {$[30]$} \\
\hline Fish market, Puerto Maldonado & 2008 & Pimelodidae & Pseudoplatystoma tigrinum & $\mathrm{N} / \mathrm{A}$ & 0.183 & {$[30]$} \\
\hline Fish market, Puerto Maldonado & 2008 & Pimelodidae & Zungaro zungaro & N/A & 0.698 & {$[30]$} \\
\hline Fish market, Puerto Maldonado & 2008 & Prochilodontidae & Prochilodus nigricans & $\mathrm{N} / \mathrm{A}$ & 0.036 & {$[30]$} \\
\hline Fish market, Puerto Maldonado & 2008 & Sciaenidae & Plagioscion squamosissimus & N/A & 0.095 & {$[30]$} \\
\hline Candamo River & 1997 & Characidae & Brycon melanopterus & $\mathrm{N} / \mathrm{A}$ & 0.044 & {$[32]$} \\
\hline Candamo River & 1997 & Erythrinidae & Hoplias malabaricus & N/A & 0.031 & {$[32]$} \\
\hline Candamo River & 1997 & Pimelodidae & Pimelodus ornatus & N/A & 0.042 & {$[32]$} \\
\hline Candamo River & 1997 & Pimelodidae & Pseudoplatystoma sp. & $\mathrm{N} / \mathrm{A}$ & 0.091 & {$[32]$} \\
\hline Candamo River & 1997 & Prochilodontidae & Prochilodus nigricans & N/A & 0.013 & {$[32]$} \\
\hline Cumeriali River & $1990-1993$ & Pimelodidae & Zungaro zungaro & 0.235 & 0.281 & {$[8]$} \\
\hline Manu River by Tayakome & 1990-1993 & Characidae & Piaractus brachypomus & 0.043 & 0.053 & {$[8]$} \\
\hline Manu River by Tayakome & $1990-1993$ & Pimelodidae & Pseudoplatystoma sp. & 0.068 & 0.086 & {$[8]$} \\
\hline Manu River by Tayakome & 1990-1993 & Serrasalmidae & Serrasalmus sp. & 0.069 & 0.090 & {$[8]$} \\
\hline $\begin{array}{l}\text { Manu River } 50 \mathrm{~km} \text { downstream of } \\
\text { Tayakome }\end{array}$ & 1990-1993 & Characidae & Piaractus brachypomus & 0.057 & 0.067 & {$[8]$} \\
\hline $\begin{array}{l}\text { Manu River } 50 \mathrm{~km} \text { downstream of } \\
\text { Tayakome }\end{array}$ & $1990-1993$ & Pimelodidae & Zungaro zungaro & 0.238 & 0.280 & {$[8]$} \\
\hline $\begin{array}{l}\text { Manu River } 50 \mathrm{~km} \text { downstream of } \\
\text { Tayakome }\end{array}$ & 1990-1993 & Serrasalmidae & Serrasalmus rhombeus & 0.088 & 0.140 & {$[8]$} \\
\hline $\begin{array}{l}\text { Madre de Dios River } 30 \mathrm{~km} \\
\text { upstream of Boca Manu }\end{array}$ & 1990-1993 & Curimatidae & Potamorhina altamazonica & 0.068 & 0.093 & {$[8]$} \\
\hline $\begin{array}{l}\text { Madre de Dios River } 30 \mathrm{~km} \\
\text { upstream of Boca Manu }\end{array}$ & $1990-1993$ & Pimelodidae & Pseudoplatystoma sp. & 1.071 & 1.113 & {$[8]$} \\
\hline $\begin{array}{l}\text { Madre de Dios River } 30 \mathrm{~km} \\
\text { upstream of Boca Manu }\end{array}$ & $1990-1993$ & Sciaenidae & Plagioscion auratus & 0.424 & 0.455 & {$[8]$} \\
\hline $\begin{array}{l}\text { Manu River } 25 \mathrm{~km} \text { upstream of } \\
\text { Boca Manu }\end{array}$ & $1990-1993$ & Pimelodidae & Zungaro zungaro & 0.057 & 0.072 & {$[8]$} \\
\hline $\begin{array}{l}\text { Manu River } 25 \mathrm{~km} \text { upstream of } \\
\text { Boca Manu }\end{array}$ & $1990-1993$ & Pimelodidae & Pimelodus sp. & 0.034 & 0.051 & {$[8]$} \\
\hline $\begin{array}{l}\text { Madre de Dios River } 50 \mathrm{~km} \\
\text { upstream of Puerto Maldonado }\end{array}$ & 1990-1993 & Curimatidae & Potamorhina altamazonica & 0.038 & 0.058 & {$[8]$} \\
\hline Fish market, Puerto Maldonado & $1990-1993$ & Cynodontidae & Cynodon sp. & 0.587 & 0.628 & {$[8]$} \\
\hline Fish market, Puerto Maldonado & $1990-1993$ & Pimelodidae & Zungaro zungaro & 0.770 & 1.008 & {$[8]$} \\
\hline Fish market, Puerto Maldonado & $1990-1993$ & Prochilodontidae & Prochilodus nigricans & 0.096 & 0.125 & {$[8]$} \\
\hline Rio de la Torre & 1990-1993 & Pimelodidae & Pseudoplatystoma sp. & 0.366 & 0.467 & [8] \\
\hline
\end{tabular}


tions observed in fish collected near mined sites [8,30] compared to those captured near more pristine sites, such as the Candemo River [32], suggest that mining is the most important source of contamination at our study site.

The gold mining that we have observed in the Tambopata River main channel occurs at a small scale; we saw only one operation during our fieldwork from May to July 2009 near the ecotourism lodge Posada Amazonas. In addition, four or five dredges commonly operate below the confluence of the Malinowski River during the dry season (personal communications, Dr. Donald Brightsmith, 2 May 2011). In contrast, gold mining in neighboring river basins, such as the Colorado and Inambari Rivers, operate at a much larger scale. Although the operations are still considered "artisanal", heavy machinery such as front-loading tractors and dredgers has caused vast changes in river geomorphology that can be observed in satellite images (Figure 1) [23]. The small scale of gold mining that occurs at our study site, high concentrations of sediments in the river that readily bind to $\mathrm{Hg}$ (II) [36], and high turnover of sediment associated with scouring floods are potential mechanisms that may explain why sediment $\mathrm{Hg}$ concentrations in the main channel are relatively low.

Because of its protected status as a conservation reservation, the oxbow lake Tres Chimbadas is not subjected to gold mining. The lake must either receive $\mathrm{Hg}$ particles from the atmosphere or from the main channel via a small connecting stream. The higher $\mathrm{Hg}(\mathrm{II})$ concentrations in lake sediments compared to main channel sediments suggest that because suspended sediment concentrations and turnover rate are much lower in the lake, there is a greater potential for $\mathrm{Hg}$ to accumulate. Sediment organic matter content also was greater in the lake compared to the main channel, and lake sediments likely are anaerobic as a consequence. Because $\mathrm{Hg}$ methylation in sediments requires anaerobic conditions, high sediment organic matter content can promote the production of $\mathrm{MeHg}$ by microbes (e.g., [37]). However, organic molecules can bind with $\mathrm{Hg}$, limiting availability of $\mathrm{Hg}$ for methylating bacteria [38]. Thus, $\mathrm{MeHg}$ tends to not be transferred to the metazoan food web in aquatic habitats with high sediment organic matter content [39-41].

Trophic position is an important consideration in $\mathrm{Hg}$ studies because it influences dietary exposure to $\mathrm{MeHg}$. Concentrations of $\mathrm{MeHg}$ in fish tissue did not increase with trophic position in the main channel, but trophic position was positively associated with $\mathrm{MeHg}$ concentrations in the lake. A strong relationship between $\mathrm{MeHg}$ and trophic position would require that consumers assimilate $\mathrm{MeHg}$ in food chains derived from the same source of contamination. Long-distance movements by consumers could weaken the correlation between $\mathrm{MeHg}$ body burden and trophic position. Seasonal, long-dis- tance migrations of fishes are commonplace in Neotropical rivers [42]. Some of the large predatory species of pimelodid catfishes are believed to move to the Andean foothills to spawn during the beginning of the high-water period in November or December, and then migrate downstream to deeper river channels at the beginning of the low-water period in June $[10,43]$. In the main channel, some pimelodid species that fed at relatively low trophic positions had high $\mathrm{MeHg}$ concentrations (e.g., Parauchenipterus sp. and mota con puntos). These catfishes could have assimilated $\mathrm{MeHg}$ from more contaminated rivers in neighboring drainage basins and then migrated into our study area.

In contrast to fishes from the main channel, the fishes captured from the lake seem to be relatively sedentary species. We seined sandbanks in the main channel several times a week from May to July 2009 and August 2010 and captured no fishes from the families Erythrinidae, Cichlidae, or Serrasalmidae, but these families were well-represented in our lake samples. Other studies also have reported species from these families to be common in oxbow lakes $[10,44]$. Furthermore, because of the relatively high elevational gradient at our study site, river water level rarely exceeds bankfull stage [23]. Given that inundation of the floodplain only occurs for a brief period of time, there is insufficient overbank flooding to hydrologically connect the lake to the main channel across the floodplain. Tres Chimbadas Lake drains to the main channel via a long, narrow (ca. $4 \mathrm{~km}$ long and $10 \mathrm{~m}$ wide) stream, and the lake appears to be relatively isolated in terms of fish movement. Thus, any $\mathrm{MeHg}$ that is bioaccumulated by fishes residing in the lake presumably originated from lake sediments. Although fishes from the lake generally had lower $\mathrm{MeHg}$ concentrations than fishes from the main channel, $\mathrm{MeHg}$ concentrations in some lake species were still higher than USEPA fish tissue criterion.

The Madre de Dios River and tributaries are currently unimpounded, but a large-scale hydroelectric project is being planned on the Inambari River. The 2200-megawatt dam would be the largest hydroelectric facility in Perú, flooding 46,000 hectares of land and causing extensive changes to the natural hydrologic regime. Because of widespread placer mining of gold in the Inambari River [10,23], there is large potential for extensive bacterial methylation of $\mathrm{Hg}$ within organic-rich sediments of the newly created reservoir. It is well documented that reservoir construction causes $\mathrm{MeHg}$ concentrations in fish tissue to rise [45-47]. Fishes inhabiting a reservoir on the Inambari River would be expected to have elevated $\mathrm{MeHg}$ concentrations.

Five out of the eight fish species surveyed from the main channel (63\%) and two out of the five species from the lake (40\%) had MeHg levels higher than USEPA fish 
tissue criterion. In the main channel, the fish species with the highest $\mathrm{MeHg}$ were migratory pimelodid catfish species of high market value. A recent study identifying levels of total mercury in human hair in the Madre de Dios Department found that mercury concentrations were significantly related to fish consumption level, gender, and location [mining zone versus city of Puerto Maldonado, 48]. Of all people surveyed that ate 12 or more fish meals per month, $18 \%$ had levels of mercury considered unhealthy (levels above $6.0 \mu \mathrm{g} / \mathrm{g}$ dry hair) by the World Health Organization [49]. Furthermore, $8 \%$ of men living in mining zones had mercury levels that are considered unhealthy. Indigenous communities in the Western Amazon have been documented to consume one to two meals of fish per day on average, and thus may be at risk of developing health problems related to $\mathrm{MeHg}$ exposure as a result of gold mining [50]. However, avoidance of fish consumption by indigenous people because of fear of $\mathrm{Hg}$ exposure can result in a switch to a western diet, associated with processed foods high in fat and low in protein [51]. Fish and fishing also have cultural significance, and avoidance of fish consumption has caused socio-cultural disruption in some indigenous Amerindian communities [52]. There are important implications for the endangered giant otter; at least one of the otter's preferred prey species, huasaco, had a high $\mathrm{MeHg}$ body burden. Five of the eight species from the main channel $(63 \%)$ had $\mathrm{MeHg}$ concentrations greater than those known to cause neurological changes in the brain of the American mink, a species from the same family as giant otter [17]. Giant otters often use oxbow lakes as core areas within their home ranges, so it is possible that the high sediment organic matter and lower $\mathrm{Hg}$ levels found in fish in protected lakes where gold mining does not occur could partially protect them from greater $\mathrm{MeHg}$ exposure. More detailed analysis of bioaccumulation in aquatic food webs, human fish consumption surveys, and estimation of $\mathrm{Hg}$ levels in giant otters would greatly improve understanding of these risks.

\section{Acknowledgements}

We thank David Flores, Andrew Jackson, and Carmen Montaña for help in the field and Abir Biswas for technical assistance. Kurt Holle, Larissa Silva, Rob Williams, and other employees from the Frankfurt Zoological Society and Rainforest Expeditions assisted with local logistics. The Ese'eja native community of Infierno granted us access to the study areas. Hernan Ortega from the Museo de Historia Natural de Lima, Perú, provided aid in obtaining collection permits. Financial support came from University of Georgia Faculty Research Program (to $\mathrm{CVF}$ ) and George and Carolyn Kelso (to KOW).

\section{REFERENCES}

[1] L. I. Sweet and J. T. Zelikoff, "Toxicology and Immunotoxicology of Mercury: A Comparative Review in Fish and Humans," Journal of Toxicology and Environmental Health, Part B Critical Reviews, Vol. 4, No. 2, 2001, pp. 161-205. doi:10.1080/109374001300339809

[2] H. M. Chan, A. M. Scheuhammer, A. Ferran, C. Loupelle, J. Holloway and S. Weech, "Impacts of Mercury on Freshwater Fish-Eating Wildlife and Humans," Human and Ecological Risk Assessment, Vol. 9, No. 4, 2003, pp. 867-883. doi:10.1080/713610013

[3] D. Borum, M. K. Manibusan, R. Schoeny and E. L. Winchester, "Water Quality Criterion for the Protection of Human Health: Methylmercury," Office of Science and Technology: Office of Water, US Environmental Protection Agency, Washington DC, 2001.

[4] J. Groenendijk and F. Hajek, "Giants of the Madre de Dios," Frankfurt Zoological Society, Lima, Peru, 2006.

[5] J. J. Swenson, C. E. Carter, J. C. Domec and C. I. Delgado, "Gold Mining in the Peruvian Amazon: Global Prices, Deforestation, and Mercury Imports," PLOS One, Vol. 6, No. 4, 2011, p. e18875. doi:10.1371/journal.pone.0018875

[6] CNN Money, "Commodities-Oil, Silver and Gold Prices," 2012.

[7] W. C. Pfeiffer and L. D. Lacerda, "Mercury Inputs into the Amazon Region, Brazil," Environmental Technology Letters, Vol. 9, No. 4, 1988, pp. 325-330. doi:10.1080/09593338809384573

[8] A. C. Gutleb, C. Schenck and E. Staib, "Giant Otter (Pteronura Brasiliensis) at Risk? Total Mercury and Methylmercury Levels in Fish and Otter Scats, Peru," Ambio, Vol. 26, No. 8, 1997, pp. 511-514.

[9] M. E. McClain and R. J. Naiman, "Andean Influences on the Biogeochemistry and Ecology of the Amazon River," BioScience, Vol. 58, No. 4, 2008, pp. 325-338. doi:10.1641/B580408

[10] M. Goulding, C. Cañas, R. Barthem, B. Forsberg and H. Ortega, "Amazon Headwaters: Rivers, Wildlife, and Conservation in Southeastern Peru," Asociación Para la Conservacióne la Cuenca Amazónica and Amazon Conservation Association, Lima, 2003.

[11] D. C. Depew, N. Basu, N. M. Burgess, L. M. Campbell, E. W. Devlin, P. E. Drevnick, C. R. Hammerschmidt, C. A. Murphy, M. B. Sandheinrich and J. G. Wiener, "Toxicity of Dietary Methylmercury to Fish: Derivation of Ecologically Meaningful Threshold Concentrations," Environmental Toxicology and Chemistry, Vol. 31, No. 7, 2012, pp. 1-12. doi:10.1002/etc. 1859

[12] IUCN (International Union for Conservation of Nature), "IUCN Red List of Threatened Species, a Global Species Assessment," In: J. E. M. Baillie, C. Hilton-Taylor and S. N. Stuart, Eds., Glandand Cambridge, 2004.

[13] F. C. W. Rosas, J. Zuanon and S. K. Carter, "Feeding Ecology of the Giant Otter," Biotropica, Vol. 31, No. 3, 1999, pp. 502-506.

doi:10.1111/j.1744-7429.1999.tb00393.x 
[14] C. Watanabe and H. Satoh, "Evolution of Our Understanding of Methylmercury as a Health Threat," Environmental Perspectives, Vol. 104, Suppl. 2, 1996, pp. 367379.

[15] C. D. Wren, "Probable Case of Mercury Poisoning in a Wild Otter, Lutra canadensis, in Northwestern Ontario," Canadian Field Naturalist, Vol. 99, No. 1, 1985, pp. 112114.

[16] A. C. Gutleb, A. Kranz, G. Nechay and A. Toman, "Heavy Metal Concentrations in Livers and Kidneys of the Otter (Lutra lutra) from Central Europe," Bulletin of Environmental Contamination and Toxicology, Vol. 60, No. 2, 1998, pp. 273-279. doi:10.1007/s001289900621

[17] N. Basu, A. M. Scheuhammer, K. Rouvinen-Watt, N. Grochowina, K. Klenavic, R. D. Evans and H. M. Chan, "Methylmercury Impairs Components of the Cholinergic System in Captive Mink (Mustela vison)," Toxicological Sciences, Vol. 91, No. 1, 2006, pp. 202-209. doi:10.1093/toxsci/kfj121

[18] C. C. Gilmour, E. A. Henry and R. Mitchell, "Sulfate Stimulation of Mercury Methylation in Fresh-Water Sediments," Environmental Science and Technology, Vol. 26, No. 11, 1992, pp. 2281-2287. doi:10.1021/es00035a029

[19] G. Cabana and J. B. Rasmussen, "Modelling Food Chain Structure and Contaminant Bioaccumulation Using Stable Nitrogen Isotopes," Nature, Vol. 372, No. 6503, 1994, pp. 255-257. doi: $10.1038 / 372255 \mathrm{a} 0$

[20] K. A. Kidd, R. H. Hesslein, R. J. P. Fudge and K. A. Hallard, "The Influence of Trophic Level as Measured by $\delta^{15} \mathrm{~N}$ on Mercury Concentrations in Freshwater Organisms," Water, Air, and Soil Pollution, Vol. 80, No. 1-4, 1995, pp. 1011-1015. doi:10.1007/BF01189756

[21] D. M. Post, "Using Stable Isotopes to Estimate Trophic Position: Models, Methods, and Assumptions," Ecology, Vol. 83, No. 3, 2002, pp. 703-718. doi:10.1890/0012-9658(2002)083[0703:USITET]2.0.CO; $\underline{2}$

[22] M. A. Vanderklift and S. Ponsard, "Sources of Variation in Consumer-Diet $\delta^{15} \mathrm{~N}$ Enrichment: A Meta-Analysis," Oecologia, Vol. 136, No. 2, 2003, pp. 169-182. doi:10.1007/s00442-003-1270-Z

[23] S. K. Hamilton, J. Kellndorfer, B. Lehner and M. Tobler, "Remote Sensing of Floodplain Geomorphology as a Surrogate for Biodiversity in a Tropical River System (Madre de Dios, Peru)," Geomorphology, Vol. 89, No. 1-2, 2007 , pp. 23-38. doi:10.1016/j.geomorph.2006.07.024

[24] M. E. Puhakka, R. Kalliola, M. Rajasilta and J. Salo, "River Types, Site Evolution and Successional Vegetation Patterns in Peruvian Amazonia," Journal of Biogeography, Vol. 19, No. 6, 1992, pp. 651-665. doi: $10.2307 / 2845707$

[25] J. Groenendijk, F. Kajek, S. Isola and C. Schenk, "Giant Otter Project in Peru Field Trip and Activity Report2000," International Union for Conservation of Nature Otter Specialist Group Bulletin, Vol. 18, No. 2, 2001, pp. 76-85.

[26] D. A. Arrington and K. O. Winemiller, "Preservation Effects on Stable Isotope Analysis of Fish Muscle," Tran- sactions of the American Fisheries Society, Vol. 131, No. 2, 2002, pp. 337-342.

doi:10.1577/1548-8659(2002)131<0337:PEOSIA >2.0.C $\underline{\mathrm{O} ; 2}$

[27] C. W. Shade, "Automated Simultaneous Analysis of Monomethyl and Mercuric $\mathrm{Hg}$ in Biotic Samples by $\mathrm{Hg}$ Thiourea Complex Liquid Chromatography Following Acidic Thiourea Leaching," Environmental Science and Technology, Vol. 42, No. 17, 2008, pp. 6604-6610. doi:10.1021/es $800187 \mathrm{y}$

[28] J. Olley, "Mercury in Fish and the News Media," Marine Pollution Bulletin, Vol. 4, No. 9, 1973, p. 143. doi:10.1016/0025-326X(73)90009-X

[29] American Public Health Association, "Standard Methods for the Examination of Water and Waste-Water," 19th Edition, American Water Works Association, and Water Environment Federation, Washington, DC, 1992.

[30] L. E. Fernandez and V. H. Gonzalez, "Niveles del Mercurio en Peces de Madre de Dios," Carnegie Institute for Science, Department of Global Ecology, Stanford University, Stanford, 2009.

[31] N. Bloom, "On the Chemical Form of Mercury in Edible Fish and Marine Invertebrate Tissue," Canadian Journal of Fisheries and Aquatic Sciences, Vol. 49, No. 5, 1992, pp. 1010-1017. doi:10.1139/f92-113

[32] A. C. Gutleb, A. Helsberg and C. Mitchell, "Heavy Metal Concentrations in Fish from a Pristine Rainforest Valley in Peru: A Baseline Study before the Start of Oil-Drilling Activities," Bulletin of Environmental Contamination and Toxicology, Vol. 69, No. 4, 2002, pp. 523-529. doi:10.1007/s00128-002-0093-7

[33] C. A. Cooke, P. H. Balcom, H. Biester and A. P. Wolfe, "Over Three Millennia of Mercury Pollution in the Peruvian Andes," Proceedings of the National Academy of Sciences, Vol. 106, No. 22, 2009, pp. 8830-8834. doi:10.1073/pnas.0900517106

[34] W. E. Brooks, E. Sandoval, M. A. Yepez and H. Howell, "Peru Mercury Inventory 2006," US Geological Survey, Open-File Report 2007-1252, 2007. http://pubs.usgs.gov/of/2007/1252/

[35] Instituto Geológico Minero y Metalúrgico, Lima, 2009. http://www.ingemmet.gob.pe/form/Inicio.aspx

[36] S. Ramamoorthy, S. Springthorpe and D. J. Kushner, "Competition for Mercury between River Sediment and Bacteria," Bulletin of Environmental Contamination \& Toxicology, Vol. 17, No. 5, 1977, pp. 505-511. doi:10.1007/BF01685971

[37] S. C. Choi and R. Bartha, "Environmental Factors Affecting Mercury Methylation in Estuarine Sediments," Bulletin of Environmental Contamination and Toxicology, Vol. 53, No. 6, 1994, pp. 805-812. doi:10.1007/BF00196208

[38] R. F. C. Mantoura, A. Dickson and J. P. Riley, "The Complexation of Metals with Humic Materials in Natural Waters," Estuarine and Coastal Marine Science, Vol. 6, No. 4, 1978, pp. 387-408. doi:10.1016/0302-3524(78)90130-5

[39] R. J. Breteler, I. Valiela and J. M. Teal, "Bioavailability of Mercury in Several North-Eastern U.S. Spartina Eco- 
systems," Estuarine, Coastal and Shelf Science, Vol. 12, No. 2, 1981, pp. 155-166. doi:10.1016/S0302-3524(81)80093-X

[40] W. J. Langston, "Metals in Sediments and Benthic Organisms in the Mersey Estuary," Estuarine, Coastal and Shelf Science, Vol. 23, No. 2, 1986, pp. 239-261. doi:10.1016/0272-7714(86)90057-0

[41] C. Y. Chen, M. Dionne, B. M. Mayes, D. M. Ward, S. Sturup and B. P. Jackson, "Mercury Bioavailability and Bioaccumulation in Estuarine Food Webs in the Gulf of Maine," Environmental Science and Technology, Vol. 43, No. 6, 2009, pp. 1804-1810. doi:10.1021/es8017122

[42] K. O. Winemiller and D. B. Jepsen, "Effects of Seasonality and Fish Movement on Tropical River Food Webs," Journal of Fish Biology, Vol. 53, Suppl. A, 1998, pp. 267296. doi:10.1111/j.1095-8649.1998.tb01032.x

[43] R. B. Barthem and M. Goulding, "The Catfish Connection: Ecology, Migration, and Conservation of Amazon Predators," Columbia University Press, New York, 1997.

[44] M. J. de Jesús and C. C. Kohler, "The Commercial Fishery of the Peruvian Amazon," Fisheries, Vol. 29, No. 4, 2004, 10-16. doi:10.1577/1548-8446(2004)29[10:TCFOTP]2.0.CO;2

[45] A. T. Jackson, "The Mercury Problem in Recently Formed Reservoirs of Northern Manitoba (Canada): Effects of Impoundment and Other Factors on the Production of Methyl Mercury by Microorganisms in Sediments," $\mathrm{Ca}$ nadian Journal of Aquatic Sciences, Vol. 45, No. 1, 1988, pp. 97-121. doi:10.1139/f88-012

[46] R. Schetagne, J. F. Doyon and J. J. Fournier, "Export of
Mercury Downstream from Reservoirs," Science of the Total Environment," Vol. 260, No. 1-3, 2000, pp. 135145. doi:10.1016/S0048-9697(00)00557-X

[47] L. D. Hylander, J. Gröhn, M. Tropp, A. Vikström, H. Wolpher, E. de Castro e Silva, M. Meili and L. J. Oliveria, "Fish Mercury Increase in Lago Manso, a New Hydroelectric Reservoir in Tropical Brazil," Journal of Environmental Management, Vol. 81, No. 2, 2006, pp. 155166. doi:10.1016/j.jenvman.2005.09.025

[48] K. Ashe, "Elevated Mercury Concentrations in Humans of Madre de Dios, Peru," PLOS One, Vol. 7, No. 3, 2012, p. e33305. doi:10.1371/journal.pone.0033305

[49] World Health Organization, "Environmental Health Criteria. I. Mercury," World Health Organization, Geneva, 1976.

[50] A. A. P. Boischio and D. Henshel, "Fish Consumption, Fish Lore, and Mercury Pollution-Risk Communication for the Madeira River People," Environmental Research Section A, Vol. 84, No. 2, 2000, pp. 108-126. doi:10.1006/enrs.2000.4035

[51] B. Wheatley and S. Paradis, "Balancing Human Exposure, Risk and Reality: Questions Raised by the Canadian Aboriginal Methylmercury Program," Neurotoxicology, Vol. 17, No. 1, 1996, pp. 241-249.

[52] B. Wheatley and M. A. Wheatley, "Methylmercury and the Health of Indigenous Peoples: A Risk Management Challenge for Physical and Social Sciences and for Public Health Policy," Science of the Total Environment, Vol. 259, No. 1-3, 2000, pp. 23-29. doi:10.1016/S0048-9697(00)00546-5 